\title{
Music and Musicalities in the Hip Hop Movement: gospel rap ${ }^{1}$
}

\author{
Angela Maria de Souza \\ Professor at the Universidade Federal da Integração \\ Latino-Americana - UNILA \\ Deise Lucy Oliveira Montardo \\ Professor at the Universidade Federal do Amazonas - UFAM
}

\section{Musical-cultural Contexts: musical trajectories in construction}

This article reflects on some questions initially raised in the doctoral thesis in Social Anthropology entitled "The Road is Long and the Ground is Slippery!: the hip hop movement in Florianópolis and Lisboa" (Souza 2009), which provides ethnographic support for the reflections raised here about this musical product. The hip hop movement and the musicalities that are part of it are associated to specificities of urban contexts ${ }^{2}$ of medium and large cities and through this inter-relationship reflect not only on these spaces, but also on a being in the world that is permeated by subjectivities that redefine musical practices. Four styles of rap were explored in the ethnography conducted in that study: the quebrada rap, Floripa rap and gospel rap in Greater Florianópolis and crioulo rap, in Greater Lisbon. This text focuses on gospel rap, yet also discusses the relationships and approximations with the other

\footnotetext{
1 The study presented here was conducted during the doctoral studies at the Graduate Program in Social Anthropology - UFSC, with a grant from CAPES and CNPq Translation of the article was supported by CAPES through the Projeto Procad NF. "A Antropologia contemporanea em dialogo com os grupos estudados “ [Contemporary Anthropology in Dialog with the Groups Studied] (PPGAS UFRN/ UFAM/UFSC).

2 The discussion about the urban contexts is quite significant and has an expressive ethnographic production, see Velho (1999, 2003).

3 Quebrada: spaces considered marginalized in and by the city, that may be in peripheries [See note 4], or may be favelas. Quebradas do not obey fixed geographic limits. The term can refer to a neighborhood, a favela, or to a few streets, but generally is used for a space of social belonging.
} 
rap styles to treat the specificities that emerge in their practices and musical experiences.

Rap music was born in the ghettos and peripheries ${ }^{4}$, and became a strong reference for youth inserted in different social-cultural and even religious contexts. While it is not restricted to Western countries, it is within this geographic-cultural universe and concept of musical production that rap was initially established. ${ }^{5}$ To reflect on what musical production means in the West is a complex task, principally in an attempt to create distinctions, borders and limits that insist on not being maintained in defined places. To the contrary, shifting, movement, and circulation are definitive and constitutive of these musicalities. ${ }^{6}$

The discussion of popular music conducted by Attali (1992) and Menezes Bastos (1995) helps to expand the notion of what is music. The idea of reserving the term music only for what is considered erudite and technical is one of the perverse effects of evolutionism when it elects a single ideal form and understands all the rest as music of the "others," often not even considering them to be music. During the 2oth century, there was an expansion in the definition of music, and with it the visibility of its forms of expression expanded.

In this perspective, populations from different cultures, even those belonging to the context of "Western culture," are presented based on their own musical knowledge. The development of ethnomusicology or the anthropology of music made previously unknown musicalities visible. ${ }^{7}$ Nevertheless, as this musical knowledge came to light, other specificities broadened this musical diversity even more, including technological advances. Technological

4 Periferia: A periphery is a space in the city that may be geographically close to downtown, but from which a distance is created by other factors, usually related to social problems. Rap has gained strength in these spaces and is recreated daily in the cities.

5 Using rap as an example, we can perceive this circulation between borders. This musical style was formed in the United States based on influences from Jamaica and Latin America, and has reached Brazil where it takes on its own characteristics and acquires unique traits.

6 In a broader context, these mobile and very often polemical borders appear to feed debates and the music itself in various genres. We can cite samba in Brazil, over which there is a dispute over the place of its rise between

Rio de Janeiro and Bahia, and the tango which is commonly considered defined Argentine, but is claimed by Uruguayans. There will probably never be a consensus about the issue, to the contrary, it is the lack of consensus that makes many of these musical practices dynamic. For a broader discussion about these national confluences that go beyond musicalities, see Menezes Bastos (2007).

7 For a general vision about the history of the construction of the discipline and evidence of its paradoxes see Menezes Bastos (1995). 
innovations of the late 19th and early 2oth centuries gave potential to the expansion of a variety of musical styles, mainly in industrialized Western societies where music also had economic value. This took place above all with the implementation of the phonographic industry and techniques that allowed the recording and reproduction of these musicalities (MENEZES BASTOS, 1995).

In another context, at the turn of the 21st century, the hip hop movement helps us realize that technology, which is so important for the expansion of popular music, is also one of the factors responsible for the form of making rap, more specifically electronic technology. Recognizing the proper temporal distances, given that the technological apparatus are different, it is this apparatus that allows making this music, and rap has come to inaugurate a musical concept. ${ }^{8}$ This technology and its uses creates the possibilities of other musical theories. While in some musical styles it is essential to dominate a musical instrument, in rap other elements, such as the command of equipment or the choice of the pre-recorded instrumental bases, perform this role. That is, musical competency is based on other values ${ }^{9}$ and the equipment can be considered a type of musical instrument. In addition, they aggregate to this technological manipulation other musical theories that come from their family, personal, and community experiences, and from umbanda and candomblé, capoeira, and percussion groups from samba schools.

The importance of the poetic composition of the lyrics, sung by the MC (Master of Ceremonies) and of the handling of the electronic equipment by the $\mathrm{DJ}$ to create the melodic base, is concentrated in rap. The reproduction of electronic sounds allows the production of rap, which is constituted as a

8 It is worth emphasizing that this musical practice is not accessible to all rap groups. Difficult access to technologies is a barrier to musical practice, which in many moments is transposed by the socialization of technological-musical knowledge and equipment, such as the handling of pick-ups, vinyl records, mixers, computers and others. At various presentations it is common to see the DJ and the equipment from one group assist in the presentation of other groups that do not have this equipment. In gospel rap, some churches help the groups purchase equipment, record music on CDs and produce video-clips.

9 In most cases, it is the DJs who know how to handle the technical equipment used in the musical production of rap. During the field work it was common to find groups in which none of the members had this knowledge and sang along with music recorded on a CD, which had been copied or produced by another DJ. It is also not rare to find groups without a DJ and equipment. Even in rap, which dispenses technological apparatus, which demands significant financial resources, it is common to find groups that make their music by counting on support and equipment borrowed from more technologically structured groups. 
musical genre that makes a distinct use of technology. While other musical genres appropriate and use these technological resources, in rap it is a determinant of the musical production. The use of musical instruments in rap presentations stirs many debates between those rappers who are against and those who defend that rap can be made in both ways, or that is, with or without musical instruments on stage.

Music among the rappers can be perceived apart from a "being in the world." They say that they sing the reality in which they live and this narrative is permeated by feelings, as music surges from the experience that they narrate. Upon singing about reality, they present their way of seeing the world. The music functions as a type of communication that criticizes and allows their dissatisfaction, discontentment, fears, anguish and revolt to emerge. At the same time, their musical narratives are created from these experiences, which is defined as reality and which allows this musical production.

Music as a generic object does not exist, it can only be understood from the relations that it establishes. Ethnomusicology ${ }^{10}$ provides us a vast and rich material that allows perceiving the great diversity and complexity this holds for us. Works like that of Blacking (1973), Seeger (1980), Roseman (1993), Feld (1982) and others, ${ }^{11}$ situate us in this universe. Far beyond the way that music is perceived in Western industrial societies, these studies allow us to consider it in a simultaneously broader and more specific manner.

Attali (1992) relates music and economics in the West and presents us social specificities that generate structural changes in the way of dealing with music in our society. The author also emphasizes that the process through which Western music has been passing makes social, political and economic changes audible. More than an object of study, music is a way of perceiving the world, given that the musical movements anticipate social changes.

Frith (1988) presents some tensions that permeate the musical world, including the impact generated in the history of rock by technical advances and their mass dissemination. He also emphasizes that the meaning of popular music ${ }^{12}$ of the 2oth century is inseparable from the use of the mass media

\footnotetext{
10 For more details about Ethnomusicology, see Menezes Bastos (1995), which offers a broad discussion about theories in this field over the last 100 years, more specifically in the definition of a field of action and of its own object of knowledge, music.

11 We can cite Tagg (2004), Seitel (1999), Elias (1995), etc.

12 The opposition between popular music and artistic music in Brazil is discussed by Menezes Bastos
} 
(radio, cinema, TV, video). The formation of this music can only be understood through this relationship. The author analyzes the industrialization of music and its implications and affirms the importance of three aspects: the effects generated by technology, the economic relations that are involved in musical production and commercialization and the new musical culture.

Frith (1988) indicates that black music in the United States also caused the emergence of elements of a new popular music. This type of music brings with it resistance to a bourgeoius hegemony. The so-called "Americanization" of music expressed through jazz, blues, rhythm \& blues, soul, gospel and rock itself, rose from a long popular and black American musical tradition located in urban and rural social spaces occupied predominantly by poor blacks. Its influences have been diffused, and received and digested by genres such as rap. ${ }^{13}$ Rap enters the musical scene as a result of cultural encounters in the United States. Although it has spread through a wide variety of contexts, rap is a music that thinks locally. In the diaspora, among immigrant populations, in religious contexts, in the peripheries, rap becomes a form of updating practices of protest, which are aestheticized by subjectivities that give form and content to this music.

\section{Rapensando ${ }^{14}$ musical production}

Rap rose through the confluence of musical and cultural practices that allowed its emergence in the United States in the 1970s among populations of the peripheries and in this context some specificities emerge that constitute

(1995). Popular music has less prestige than artistic music because it does not involve "knowledge," while folkloric music is not considered authentic. Menezes Bastos (1995) proposes that "popular music" - exemplified in Brazil by samba - should be understood as a style that is between "artistic" and "folk" music, but which is constituted as a "third 'universal' in the West, whose core was consolidated in the 1930-196os around 'jazz-rock' which indicates a planetary world system" in which "universal is conceived as a language that sets limits of a determined socio-cultural system ('universe')" (p.5)..

13 The bibliography produced in recent years about the hip-hop movement and rap has grown significantly in quantity and diversity and here are just a few first indications of these discussions: Rose (1994) - about the U.S. hip hop movement; about influence of U.S. music on genres such as funk in Brazil see Vianna (1988 and 2003); on the hip hop movement in Brazil see Herschmann (1997, 2005) and Dayrell (2005); about Greater Lisbon see Fradique (2003), Cidra (2002). Contador and Ferreira (1997) sketch the initial practices of hip hop in Brazil. For more references about the hip hop movement in Greater Florianópolis see Souza (1998 and 2009), etc.

14 From the verb Rapensar (Rapthink, and a play on words with the word "repensar" or rethink), title of the $C D$ of the Portuguese rapper of Cape-Verde descent, Chullage (2004). 
this musicality. Blacking (1973), in his field work among the Venda of South Africa, during which he had contact with their musicality, began to rethink the way that their music was formed, that is, as an organized system of sounds, according to rules and variations of a European matrix. In this ethnographic context, the author perceived that this form of organization of sounds is only one among many. For the Venda, music does not have value in and of itself, it occurs in the interaction with people. Thus, its signification is constructed in the social environment, and is based on the feelings and social experiences of those who create it, and this highlights a point of approximation with rap for which the composition indicates an experience that is sung, which involves feelings and emotions that presuppose interaction, principally, in the spaces in which the narratives were elaborated. ${ }^{15} \mathrm{It}$ is in this context that the music takes shape. Rap takes form in this confluence of musical-cultural experiences and knowledge. In this sense, the subjectivities that emerge in these raps are among its principal characteristics. To sing from one's own experiences, one's own realities, is a structuring element of this musical production.

The song Brasileira-mente [a play on words that could be read as Brazilian-mind or Brazilianly], by the group Arma-Zen [ a pun that could mean Zen-weapon as well as warehouse], narrates the experience of a proximity with violence in the sense of calling attention to its presence and consequences: My ears have heard, my eyes have seen / Risk is the danger not of my writing but of my enemies/ Flying through the sky, bullets decorating the landscape/Tears of blood cloud the eyes of the city/It was no film, not a fulllength feature/Here it's reality, periphery college/Where I learned the art of expression at the foundation [...].

The music begins by establishing a corporal proximity with this violence. This is a body that is at risk, from both the police and from criminals, given that the singer is young, black and a resident of the periphery, in other words, the public that is most affected by crime and by violence in the large and medium-size cities of Brazil. And in this narrative the police are in a 
helicopter, flying over the sky with bullets decorating the landscape, which generates losses, generates tears. The song then reinforces the dimension of reality of which it sings in opposition to violence as portrayed in films. Nevertheless, this same periphery, with its violence, is that which teaches him to sing, to rhyme and express himself through the art of making rap, or making poetry based on violence.

The music emphasizes the relationship of friendship that strengthens them and makes them change, and here this mention of this change of phase, sung in the first person, appears to be directing us to think about limits. That is, the line that separates those who are and those who are not in another phase is very tenuous. Nevertheless, it is in this phase that is found the risk, the betrayal, the malice, drugs and unhappiness at his side, and as a defense, friendship is the bond here. If in one of these phases friendship is determinant, in the other, it does not exist, given that one who appears to be a friend can be a traitor, or driven by money, by personal benefit, by the advantage getting ahead, by treachery, or as the song states later: this is how it is, today he's your brother and tomorrow kills your own partner.

This threshold situation that the music presents, and of insecurity principally in relation to "friendships," is present in various musical compositions, mainly of groups that inhabit these spaces in the periphery and for whom urban violence is a theme of their music. The difficulties are narrated: All the stones in the road are removed, yes/All of our sagas are contemplated / Me, with baggy clothes and silver chains/ The beloved country gentle mother / Give me strength so that my face is not beaten / So that a revolver does not make my dear mother cry. The difficulties are confronted with the aesthetic-musical practice, represented here by baggy clothes and silver pendents. But, in addition to the difficulties and the search for alternatives, an anguish is created, the risk of death and of my dear mother crying.

The mother is associated to the country, which in turn is the dear sweet mother, from the words of the Brazilian national anthem: "The dear worshipped country, hail, hail", a verse that is not in the music, but to which it makes a reference in the comparison with the mother who, regardless of the situation, will always be ready to receive a son. If a soldier after a war wants to be received by his country in the same way that he would be received by his mother, here the mother is this country, but it is a mother who should be preserved and protected so that she does not wind up crying over the death of a son. 
This mother, who appears here is also the mother country, but here the relationship changes. Given that this mother is often negligent and leaves her children abandoned to their own luck. This mother country is represented by the inequality and lack of opportunity that expand the violence. But this absence does not cause us to give up. On roads traveled I continue on my path/I remember that all rosebushes have thorns / I want to leave for my children, more than affection and caresses/My record is like this, I live and I survive/But how is my writing. A relationship of continuity is established through these verses, as if it were an inheritance left to his children, which could be a record, or his account.

Later on in the song, the mother country is mentioned again, but this time in the past, as a way to remember the marks that the past left in the present. Of all the races that carry suffering on their face/Marks of swelling with calloused hands / kilos of Brazil wood were taken in those ships/ The crown that salutes enslaved us/Days passed, our mind chained, alienated/504 years later there are still marks / Scars that are still in our thoughts. And here the consequences of slavery are located in the peripheries in a relationship of expropriation, exploitation and violence. Here the country is not absent, it leaves scars on the population, who it used as slaves, given that it took their labor and left as an inheritance the bondage that they have not erased in five centuries. The song emphasizes the word coroa, which can be the crown and a symbol of royalty. But it is also a word used popularly as a synonym for mother. Here, The crown who salutes enslaved us has a dubious and negative meaning associated to slavery and exploitation of the people and riches of the earth.

The city then comes into play through its contradictions when the music asks: Which ghetto do you prefer?/ To live forever in heaven or here in hell?/ Modern, with lots of houses and cars, paved streets and buildings. Heaven only comes with death, while hell is here. But this is a hell for some and which is outside the modern world. This ghetto implies a relationship of consumption and inequality between those who have access to these goods and those on the outside who watch without being able to obtain them. And it continues to reinforce the belonging to the ghetto, except that based on what it produces: This is the ghetto, apology and knowledge...Even so, self-esteem falls to earth, mainly when facing the memory of friends who have already died, and they ask: Where is Chica, ${ }^{16}$ Mano? And the response follows: In the cemetery. The fear of the

16 Chica is a friend who has died and is paid homage to in the song. 
suffering mother returns, now through those who have already suffered loses: Many mothers pray for the children they have lost. And, Which the MCs, verse, prosper, don't wait to fall from the sky, calling for action against those who dare, and need to be active, take initiative and have a determined posture in the search for better conditions. I get pen and paper and write/In reality I will sing and revive my values/The consequence of the oppressors brings me illness and pain/The scar on my soul caused by time/Does not fill the gaps, which is the rupture / I closed the window but left the cracks open/It took a few conversations so I wouldn't fall to earth/ Evil airs, a few bars, a few places. Here as well, history returns through the experience of an uncertain and insecure present, pointing to the marks that the past imposes and that on many occasions left a doubt about which route to follow as the last lines recall. And I highlight the final portion of this narrative to reflect on some factors highlighted in the song:

Bullets scraped my body in the past

And I saw that 10 percent of me has gone to clay<smiles>[AlH]</smiles>

Fear grips the entire city

My eyes tear with longing

When it's not crack, coke, needles and happiness

Brothers die and die, no one saves them

Where is Jesus who died for us on the cross

Send me strength through the divine light

Here periphery, lost lives

Bodies, at the mercy of all the villainy

The crazies like rap, and come like ants

A number of issues are raised again in this ending. The first of these refers to the violence they experience and indicates this proximity through his body, in the verse: bullets scrape my body. But the metaphor takes on dimensions of reality upon recalling the deaths of friends. It mentions drugs, in this relationship with violence, and calls for Jesus in a search for help. And religion, or the search for a spiritual assistance, is present in this music, it is a second factor that is in many of the songs and that is activated mainly by 
asking for help or in the attempt to minimize great pain, usually related to the loss of someone close. Finally, the city is indicated here in the reference to the fear to which he is submitted. That is, this city is the scene in which this experience takes place, whether in the periphery or outside it.

Before the end of the music, two lines stand out: In reality I do not need and have no fantasy about my style / That's how I live and I multiply in the place where I reside. It is here that the territoriality of a rap style is revealed, which is in the periphery, and which sings about what is experienced there, constructing a counterpoint with the rest of the city, given that it does not need a fantasy to give life to its musical compositions.

To conclude, I return to the title of the music Brasileira-mente to highlight that, by using a hyphen in the middle of a word that demonstrates belonging, and by highlighting the word mente (which can mean mind - and is also the adverbial suffix equivalent to "ly"), the authors of the music expand their meaning, suggesting both a sense of belonging, as well as the need to reflect about this condition which makes them Brazilians. There is a plurality of meanings flourishing in the song that lasts 6 minutes and 36 seconds and in which only the two final sentences are repeated. The music calls constantly attention to a situation that is found at the peripheries, but not exclusively there, which is that of violence. They return to the past to find the causes of this violence, point to its consequences in the present, but reinforce at all times the belonging to this same periphery from which they do not want to distance themselves. There is in this posture a demarcation of the belonging to the city, but specifically to some spaces of this city. Meanwhile, the other city is made unviable, that of the Florianópolis that many know as Floripa in a reference to its natural beauties and tourist attractions. This city makes the periphery invisible, mainly in the media and its representations for tourists. While the city that constructs negative images about this periphery is, in the music, relatively invisible. This city is not exempt from the production of violence experienced in the periphery, to the contrary, it is seen as part of this production. ${ }^{17}$ In this way, they call attention through the aesthetic-musical creation to questions that touch them where they live, mainly the peripheries, and this call expands the discourses and representations about the city of Florianópolis, placing within it problems such as violence, drug dealing, etc.

17 To expand the discussion about violence see Maffesoli (1897), Wieviorka (1997), and others. 
Some issues that appear in the song presented here are important when considering some factors commonly found in the musical production of rap. First, and something that many rappers call attention to, refers to the experience that is being sung about. This causes the music to construct a truth to which they call attention. The second factor is related to the first and is generated in the emotional experience that refers to the proximity to what is being sung about. It is not enough to witness or experience what they sing, the proximity and the emotional involvement are determining factors in the construction of this reality about which they sing. It is not enough to sing about what they see in the streets, or even in prison, but what they experience in these spaces as personal experiences. They are experiences that mark their lives, which bring moments of reflection or of musical production. In gospel rap, in addition to the music, it is common to find in the meetings, what they call testimony. To speak about life, mainly the difficult moments they undergo, reinforces the repentance. Renovating the faith in Christ through this testimony is another way to manifest these lived and personal experiences, which in various situations reappear in their musical productions. In this sense, they construct performances to report on their experiences that give them legitimacy, both in the church, as well as in the production of rap.

This emotional experience conquers its legitimacy in the event, mainly in the neighborhoods/spaces of origin or preparation of the musical narratives of these rappers and in the case of gospel rap, also in the church. The legitimacy is constructed by the return from the public that participates in the event. To recognize oneself through what is presented on stage defines much of what is called truth. In this sense, the performance is a determinant of this legitimation. A performance at an event is similar to how a discourse is updated. The event allows keeping a discourse that is defended current.

The notion of performance is essential to sketching an understanding of this universe. Bauman (1977) proposes the development of the concept of verbal art - human communication - as performance, emphasizing the need for interdisciplinarity, or that is of dialog between anthropology, linguistics and literary criticism, for a broader understanding of its use as a concept. ${ }^{18}$

18 To rethink the concept of performance, Baumann (1977) tries to understand it from the unity between the aesthetic genre and other spheres of verbal behavior, presented in the concept of "verbal art" as a route to speech, with forms understood ethnographically, based on culture. For Baumann, the act of performance is located in behavior and gains significance in its context. But the event is more important as an 
It is in the event that the performance occurs, in which there are structuring elements, in addition to the performer, the participants ${ }^{19}$ and the "listeners." The act of performance keeps social practices current, and there is an intrinsic power in its practice, which is the transformation of social structures. "The consideration of the power inherent in performance to transform social structures opens the way to a range of additional considerations concerning the role of the performer in society" (BAUMAN, 1977, p.45).

Performance has a transformative role because it says something, it issues a message. The reception of this message generates changes, transformations and constructs movement, a language, which in addition to speech, uses other resources such as music.

For Bakhtin (2003), language supposes the diversity and complexity of its constitution. To understand language it is necessary to consider the use of the utterances that compose it. "These reflect the specific conditions and the finalities of each of the referred fields not only by their content (theme) and by the style of language [...], but by their compositional construction" (p. 261). But, to better understand the utterances, it is essential to consider the notions of field and genre of discourse. ${ }^{20}$

Another important factor emphasized by Bakhtin is the style of the utterance. Style and utterance (its typical forms, the genres of discourse) are interrelated. This style is defined by the genre of discourse from spheres of human activity and communication. Changes in the styles of language reflect changes in the genres of discourse. "Utterances and their types, that is, the discursive genres, are drive chains between the history of society and the history of language" (BAKHTIN, 2003, p.268). He emphasizes that it is

organizational principle in the ethnography of performance.

19 Based on Bakhtin, Baumann (1977) indicates that the role of one who hears is fundamental in the utterance, given that the speaker and the listener are subjects. This relationship is repeated in performance. A performance presupposes and requires for its existence, participants who watch, this presupposes subjects with whom a relationship is established. This situation can be exemplified in the work of Seeger (1980), among the Suyá Indians in Brazil. Even though music is a predominantly masculine activity, it is for the women (sisters and mothers) that they sing. The females compose the musical performance and the men want and need to be heard by them. The women are not only listeners, they themselves are constituted as subjects in this relationship of communication.

20 In relation to fields, Bakhtin (2003) says that they refer to human activity, they are fields of communication, Concerning the genres of discourse, for Bakhtin "each field of utilization of language elaborates relatively stable types of utterances, which we denominate as discourse genres" (p.262). The variety of discourse genres is endless and quite heterogeneous. They vary in relation with human activity, the fields. 
essential to understand the utterance also from the relations that the subject establishes, there is no isolated subject who speaks, communication is only established through a listener. The listener is as important as the speaker for understanding the utterance, which gains form through the relationship, through dialog.

Thus, rap can be understood as a discursive genre, composed of utterances. The relationship between the speaker and the other participants in the communication defines the utterance given that this is established in dialog. The music thus plays the role of establishing communication. The construction of the utterance is permeated by the subjective relationship of the speaker with the content and the meaning of his or her speech. Thus, there are no neutral utterances, they are the result of a subjective process with the content being established by the speaker, and by his subjective relationships. This value relationship of the subject with the content of the utterance is also determinant of the choice of the resources of speech and the composition of the utterance.

The role of the other, an active subject in this relationship, is determinant in the utterance, which, as Bakhtin (2003) emphasizes, has an author and recipient, contrary to words and prayers found in isolation. The way that the content of this utterance will be expressed is also determined by the field in which the recipient is found, or that is, genre and style are determinants of this relationship. Continuing in this direction, the words of a rap song construct a discourse with objectives that the songs define in the sense of portraying a reality. Thus, it is in the subjectivity of the person who constructs these raps (utterances) that this discourse is constituted, or it is in the interaction between one who writes, sings and who listens to this music.

An example of this situation, found in field work, occurred in the event Favela Agradece II, [The Favela Gives Thanks II] in the neighborhood of Monte Cristo, at the Panorama housing project. It was held on a Saturday afternoon, which allowed many children to participate actively throughout the event. It was also possible to see some of the daily movement of the condominium. Mothers came to see their children who were playing. An older woman with an aluminum bucket full of washed clothes that she was hanging to dry outside the building. People passed by with shopping bags and slowed down to see the movement. It was an afternoon with a cold south wind at Panorama and lots of rap music in the background. 
The first presentation was at 3 PM, by the group Reverso, a gospel rap group. The stage was busy, the groups took turns and the crowd was active. The presentations came one after another, with declarations, thanks, improvisations and presentations by the B-boys (break-dancers), whose show drew applause. As the afternoon moved along and night drew near, it came time for the presentation of Arma-Zen. The small stage was filled with the 7 members of the group. By this time, there was a larger crowd in front of the stage. The children were closest and paying attention, followed by fans, friends and the general public.

During the presentation of Arma-Zen, it was possible to perceive the importance of the realization of this type of event in the group's own neighborhood. The people sang along with all of the songs, they knew the rappers. At the end, the group sang the music Elegia, and made a type of homage to their colleagues and friends who had died. They mentioned a few names, which were repeated and applauded by the public. This created a commotion that extended for a few minutes with the recognition and participation of the public. Whose names were they? People who had been close to the rappers and the public. The song "A Caminhada é Longa .... e o Chão tá Liso!!" gives a hint about who they are: $A$ bunch of my friends, just fun in the past/Here in the present, most of them, are buried/ Some even married, went away calmed down/ Others who today I remember by their picture.

Who were these people that are referred to in the music? The names indicate they were all men, young and mostly black. The urban violence affects a significant portion of the population with this profile, which is the same as the rappers. But returning to the event, the time of this presentation allowed observing how important it is for the public to recognize this practice. The music sung by those who were there, the recognition of the context sung, the mentioning of the names of people known, demonstrated the great importance of this proximity. The performance was in group. Everyone sang the long lyrics of the songs and saw themselves in the narratives.

The "event" became, in this case, the space for use of a discourse about themselves in a close relationship between the singer and those who listen, applaud, repeat, and join together in a chorus that raised the volume of the discourse. The event amplified the ideas they defend and the struggles they confront in order to construct changes in the way certain urban spaces in the city and the populations who live there are seen. Once again we call attention 
to thinking about the style ${ }^{21}$ that these raps establish upon reflecting upon the different performances. In the most distinct styles, whether gospel rap or quebrada rap or rap Floripa, they have in common the sense of importance of the performance, which is revived through the event and redefined in the practices of the hip hop movement, collaborating with the diversity of which it is a part.

And of the styles that I mentioned, the quebrada rap in Florianópolis intensified, through the performance at the "event," in relation to the neighborhood of origin of the groups. It is the event that strengthens the relationship of the group with their neighborhood through sociability networks. In gospel rap the event is not less important, but its relation passes through other routes and more than the neighborhood, which is also present, it is the religious character that establishes this relationship constructed in the event. And, in these relationships, some issues interpose and redefine musical practices.

\section{From RAP - Rap, Attitude and Protest to RAP - Resgate de Almas Perdidas [Recovery of Lost Souls]}

In the hip hop movement, rap is generally seen as music of protest and questioning. Although there were prayers, and frequent references to God and Jesus Christ, earlier fieldwork in Florianópolis (Souza, 1998), did not find religion to be a territory in which rap was located. The researcher had found rappers who attended a Candomblé center and who had statutes of the Virgin Mary, the Holy Spirit and Preto Velho in their homes, but had never seen any one of them professing their faith in any religion. Informally, many say they believe in God, but this does not relate to religious practices.

Now, however, the presence of religious factors is quite common. One example is found in the song Cabelo Black Power, from the group Realidade SBA. In this song, Jesus Christ is also considered a revolutionary, and they see themselves in him because of his attitudes, as the music says: We are the image and likeness of the master/cabelo black power and suffering on our backs. The music presents a non-white Jesus Christ, with black power hair and who carries a cross, associated to the consequences of racial discrimination. There is here a demystification of a white Jesus Christ found in the imaginary of

21 We conceptualize rap as a musical genre, and appropriating the use of the native term, we use each respective style to define the subgroups that are part of this genre, such as quebrada rap, Floripa rap, gospel rap, which are all in Brazil, and rap crioulo in Portugal which is addressed in the ethnography Souza (2009). 
many religions. This is emphasized by his non-acceptance of various situations against which he struggled, giving his own life, and which made him a revolutionary. The resignified image of Christ is expanded in the association with the people and with the suffering that he carries, establishing the critical tone of many raps. And, as indicated by Novaes (1999), referring to the group Racionais, there is a strong emphasis on the triad negritude/violence/ religion which is not exclusive to rap, but is strongly marked in this musical genre, and in the periphery.

Religious issues had not called Souza's attention during her fieldwork in Greater Florianópolis (1998), and consequently she never raised significant questions about the issue. That is not until she encountered an unusual situation at the beginning of her field work for her doctorate in Social Anthropology (Souza, 2009) when rappers commented that two of their colleagues, who were initiators of rap in the city, were attending an Evangelical church, and that for this reason had given up the music. This situation was not an isolated fact and some rappers continued in the hip hop movement even after their religious conversion and this raised some doubts. Religion and rap did not appear to be able to combine side by side, and the difficulties in understanding this partnership continued. It is common to find at rap events narratives charged with emotion. It is also common for a song to provoke moments of euphoria and ecstasy in the public. But, finding all of this within a church and having Jesus Christ as the great mediator of this relationship, was, initially, a strange sensation. In countless raps, from groups in Florianópolis and various other places, I found the mention of God, Jesus Christ, Orixás, praying, and requests for blessing as something quite common and constantly present in the musical narratives that combine Catholic religious symbols and Afro-Brazilian religions, such as Umbanda and Candomblé. What at first caused perplexity was the use of rap as a tool for Evangelization as the gospel rappers themselves affirmed. While people in various musical genres, such as reggae, forró, pagode and even heavy metal make music for Christ, or become gospel groups, this relationship did not appear to make sense in relation to rap, although this was reconsidered during the course of the field work.

While accompanying the hip hop movement, this new form of singing rap continued to raise questions. Yet, it later became possible to perceive that it all made a lot of sense. A rapper, who is an MC or Master of 
Ceremonies has much more in common with a pastor than I first realized. Oratory is one of the common elements. Recognizing their distinct proportions and the criticisms that both parties (churches and rappers) generate, when the rapper is on stage, his objective is to transform the audience, which is something I heard a number of pastors say about their goal. A pastor says that he wants to touch the heart of the person who is there and the rapper, in a certain way, wants to touch the conscience of that person and both performatize this intention in musical-religious events. Both the pastor and the rapper use emotion to come close to the listener. It is common, between one music and another, for a rapper to present the situation experienced in the music as the account of an experience, or a testimony, as I heard frequently in the gospel style church. The experience in rap or the testimony in the church are determinants to provoke change and gospel rap establishes a junction of these two forms of expression.

Along with the hip hop movement, the field work entered the churches and attended weekly meetings of the BRC - Banca do Rap Cristão. ${ }^{22}$ Observing the gospel rappers on stage, and the pastor presenting his brief service, it was possible to find very similar behavior between the two. Both place in practice a "performance" that distinguishes them from the others, precisely by their command of public speaking and oratory. This calls attention to what they place in their music or preach in their services, even if they have different objectives. At various moments, rappers were on the stage/altar, performing this dual function and some of them said that they wanted to train to be pastors of their churches. To have command on stage, to speak well in public, or that is, to interact with the public, is essential for both a rapper and a pastor. In this sense, the rapper uses this performatic practice with Evangelical objectives.

In gospel rap, God is the great guide for the words, the daily practices and the "lifestyle" ${ }_{23}$ of the rappers. They come together, in this style, in the name

22 BRC - Banca do Rap Cristão [Christian Rap Bureau] combines different churches, including Renascer em Cristo, the Assembly of God, Filadélfia, Bola de Neve, Baptist, Quadrangular, Brasil para Cristo, and others located in downtown Florianópolis. This Evangelical character changes the religious ties of rap and even for it to present religious aspects, mainly Catholic and Afro-Brazilian, or from the world of gospel rap, creates a type of purification of rap, which becomes a music of Christ. With this rupture, it comes to have a religious mission, as shown by Novaes (1999) when this style of rap arose in São Paulo.

23 The concept of lifestyle used here is based on the discussions of Bourdieu (1994), followed by the contributions of Featherstone (1995), who gives special attention to the discussion of consumption. This theoretical discussion was complemented by a discussion about aesthetics implemented by Ferry (1994), for whom subjectivity and art are essential for considering these concepts of aesthetics to which 
of their faith and use rap as an exercise in their religious practices in encounters that bring together groups with objectives that are very similar, but quite heterogeneous, even from their Churches. The aesthetic-religious experience defines the style of rap of which they are a part and which combines different churches, distinct social classes, and even the most divergent opinions about what they define as gospel rap.

When I first met them at the BRC, they did not stand out. Their style of dress was the same as any other rapper, with baggy clothes, sneakers, silver chains, baseball caps. Upon seeing them sing, at first it was not possible to realize significant changes in their way of singing. But when I saw them stop, listen intensely to the words of the pastor and begin to pray no less intensely and speak in the language of the angels ${ }^{24}$ - and all of this at a rap meeting - this was surprising. Although it was at first strange to experience that strongly emotional moment in a church during a study about the hip hop movement, I gradually perceived through rap's longer history and origins, its close ties with religious practices. In this sense, the music and the musical performance come to take on another meaning and the gospel rappers respond to criticisms of their religious option made by other rappers by affirming their belonging to this musical practice, which originated with Pentecostal blacks in the U.S., for whom musicality has great importance in their religious practice. With this argument, a number of these rappers seek inspiration for their gospel musical practices in genres such as the blues, and even use musical instruments common to these genres.

This belonging to a Biblical commitment and to Christ, as they say, was what called our attention as a mark of belonging to a style of rap. This musical production is also a tool used to reach their objectives, or that is, to Evangelize. In this sense, gospel rap, as a member of the Grupo Reverso indicated, is a form of having the message of God enter the brothers' heads. He defines himself as Malokero de Cristo, for whom Humility precedes Honor, the name of the group's CD.

we aggregate the concepts of lifestyle and rap.

24 On a number of occasions it was possible to find rappers and other people presenting the services and speaking in a way that I was not able to understand, but it was always possible to perceive a great ecstasy, a moment of great vigor. Upon asking, after one service, what it meant, one rapper said that it was the language of angels. He left soon, but his wife continued to explain that when a person is able to speak the language of the angels he or she is filled by the Holy Spirit and this is the highest moment that shows that this person accepts God in his heart, in his life. 
Even with God as the main focus in this style of rap, places of the city such as the quebradas are essential and determinant. It is in these places that this style will make its mark that distinguishes and defines it as gospel rap. It is in these spaces of the city that they will exercise their practices of Evangelization for which rap becomes an important instrument. In the song, Fim do Pesadelo [End of the Nightmare], by the group Reverso, the city comes to light through its quebradas, with the problems caused by drug use and dealing,

The routine of the ghetto is like a nightmare, tell me if it's not

A crazy guy running with crack in the hands of the cops

With no structure, no faith (...)

I am with God, who is much greater than any problem

Who instead of joining his son and forgiving, he builds the truth

He extended his hand, gave me the mission that through the word, frees you from the prison, frees you from illusion and from all the evil for the cause (...)

Surrender your life to God

Awake before Christ descends

Dreams and illusions

Desires and deceptions

Confusing my illusions for a long time

Until the Lord heard my plea

And ended the nightmare (...)

The city, the problems, the people most susceptible to disappointments and to obstacles found there, appear in this song as in many other raps. But more than just rap, the song presents the option to surrender to Christ, which they define as rescue, which is associated to decision making, awareness of one's situation and a change of life. In gospel rap this rescue is conducted from a decision to surrender one's life to God, as members of the group Reverso ${ }^{25}$ affirmed

Because many people say that rap, rescues, that rap changes the life of the youth [...] But, to transform a life that is dependent on crime, on drugs, to transform a life that is already involved in drug dealing, to rescue a life from

25 The interviews were conducted with more than one member of each group and the name of the group is used to refer to their declarations. 
prostitution, this is not work that rap alone is able to do [...]. That is where there is the power of God, where only the power of God can make the difference.

Rap rescues, as they say, but its power of change is limited. Who has this power is God. Only God can, in fact, rescue and make someone follow the route considered to be good, they affirmed. However, in this case, rap assists in the rescue. For the members of Reverso, rap winds up being an instrument of God to rescue lost souls. In gospel rap, the drugs, easy money, the fun, the prostitution, everything that leads to addiction is associated to temptation. Here it is no longer society, politics, racism or inequality that cause most of the problems and difficulties experienced by youth, mainly those who are residents of the periphery and favela, but the devil himself through temptation. There is a transfer of the responsibility of problems, which should thus be confronted in a struggle of God against the Devil, until the day in which Christ descends. And this is the moment many wait for and expect, and for this reason, they need to be prepared for the day of the settling of accounts and only through faith, through the surrender of their life to Christ, according to the words of the Evangelical, will they be prepared to obtain salvation as a few told me.

The peripheries and favelas are spaces of action and residence for many members of these rap groups, as is possible to realize upon accompanying them. Although their action is not restricted to these spaces of the periphery, to the contrary, they seek to expand it to the maximum, they make it relevant by the experience of the many daily problems which are known by many of these rappers, as members of the group Culto Racional affirm, referring to an event in which they would participate in the neighborhood of Monte Cristo:

Like there in Monte Cristo, there it's going to be really cool, because the rap is a strategy, it's a strategy to place us in the periphery, in the ghetto, in the quebradas, in the hillsides, the favelas, where it's hard to find a traditional pastor, the missionary, the traditional Evangelist. Because they accept rap. [...] This is rap. The language of the ghetto, of the periphery is rap. So it's been a good strategy.

Culto Racional shows us that the music is at the service of religion, this is the strategy that they use, or that is, rap is used to enter and Evangelize in the quebradas. They einforce the point by emphasizing the insertion that rap has in these spaces, it is the language of the ghetto, which makes them well received. These rappers affirm that rap, as an instrument of Evangelization, expands access to spaces considered difficult for other members of the church 
to enter. For them, rap is an "attraction," a musical genre that has strong insertion in the quebradas, and for this reason becomes more efficient in achieving its objectives, or that is, to Evangelize. This factor is essential to understanding the relationship that is established with the public. More than musical performance, a religious performance is in question here. Although the members of the group live in neighborhoods of the periphery, the quebradas, their musical practice is not defined solely by this characteristic. It is the faith, the Evangelization, that distinguishes them and this rap that also is made in the "quebradas." More than a specific geographic location in the city, this style of rap is tied to a spiritual-religious experience that is determining of its practices and which is distinguished not by belonging to a Church, but by surrendering their lives to God. This creates a central value in these spaces, an "order" that was also observed in a study conducted among Brazilian football players who play abroad who are Evangelicals, as mentioned by Rial (2008, p. 37-8). "The belief in God has a fundamental role in the consolidation of a rigorous personal ethic," in which God, and not the religion has a determining value in their lives and their attitudes, according to Rial.

To surrender one's life to Jesus Christ is determinant to establishing an "order" in their lives. The family, marriage, prosperity, are values to be followed. The religious conversion is a break that reorders the chronology of their life: a number of them speak of a "before" and "after" of the surrendering their life to Christ. In the "before," their lives were associated to drink, drugs, prison, infidelity in love or marriage, disobedience of their parents, to a life without rules, and without meaning. "After" surrendering to Christ, all of this changes and the family, marriage, the non-use of alcohol and drugs are values to be followed. Their lives, as presented in these accounts, come to have an order that did not exist before, and they attribute this change, to God. Their music calls for this change, for the order.

Gospel rap is quite recent in the hip hop movement in Greater Florianópolis. Many of these youth were rappers before their conversion and this change in their lives marks a border between gospel rap, which they practice, and mundane rap, as they define what they practiced when they explain the moments in their lives through rap. This positioning does not have rigid borders. To the contrary, openings are always present, mainly involving religious conversion. It is possible to find people who are in the process of conversion - that is leaving the mundane - or who are switching churches, for a wide variety of reasons. 
In gospel rap, the reference for the construction of their musical narratives is a belonging defined by faith in God. Meanwhile, the quebradas, where many live, are locations from where many of the themes of these narratives emerge. The locations are important to their compositions. It is the place from where they gather references and at which they direct the rap for purposes of Evangelizing. For this reason, they narrate their own experiences of change, the departure from a world of gloom and darkness, or simply from a life without meaning, from which they say they could not see a way out.

Thus, it is an option for an experience related to a life with Christ, as they say, and not a religious life, as was thought, given that for them religion or the church to which they affiliate is important as a function of something that joins all these churches, faith. This is the characteristic that stands out, as an option for life, a determinant in their musical practice within the hip hop movement and which is defined as a lifestyle as members of Culto Racional told us.

$[\ldots]$ many people see rap as a type of music, as a way of promoting ideas and revolution. [...] But we use rap as a tool to present a new lifestyle. Our lifestyle is to have a life with God and what we want through rap is the conversion of people so that they can believe that Jesus Christ is the only and will be the only savior. So this is the distinction that drives us [...]. We go for the souls. [...] We serve God with rap and the revolution that we want to make is spiritual [...]. We don't sing to practice, but practice to pass along in the music that which we see, which we think is interesting (Culto Racional).

This lifestyle that Culto Racional presents is distinguished from the other groups because they make gospel rap, which changes the proposal for revolution within rap. A revolution continues to be important, but here it is based on the word of God, which justifies and nourishes this practice and constructs a lifestyle, it is a distinction. If in quebrada rap it is the community, the neighborhood and the relationship established with it that comes to light in the musical narratives, in gospel rap it is the word of God that occupies this place and constructs a lifestyle through the use that they make of rap in their experience. The word of God is what constructs the revolution or the questioning, which was so perplexing at the beginning of the field work, because the questioning seemed to be absent in this style of rap.

The group Reverso gives the same tone to the role of rap in their life. 
When they speak of a mother, with her prejudices, who goes to the church to see what her son is doing in the meetings of the BRC - Banca do Rap Cristão. As much as her vision of rap itself has changed, in the church, gospel rap loses its mundane character and undergoes a type of purification, as we see in their declarations.

So she came, even with a bit of prejudice, because with the excuse to defend her son, she came to know what was the purpose there. She came a bit hesitant, concerned, and at the end of the meeting she left crying and hugged us asking us to forgive her because she saw that that was really something of God and that God was leading us to use this strategy, not that we see rap only as a strategy, [...]rap has already marked my life, I cannot forget what rap has done for my life. But she saw that was a strategy of God to be offering youth the opportunity to be enjoying the music that they like [...] without needing to contaminate themselves with the bad influence of the people who do this in the secular realm (Reverso).

He sets a tone that reassures his mother, or that is, he makes clear that there is no contamination by certain practices associated to rap. Gospel rap, in his words, has the role to purify rap, by removing bad elements that can be an influence. Nevertheless, another factor present in this statement is that the entrance of rap to the church has a dual function, to attract youth and have them maintain their styles, even if these styles undergo significant changes, like this purification of rap. And this conversion of rap will allow this music to remain as an important practice that defines a "lifestyle." These rappers do not want to enter churches without being able to maintain their practices within the hip hop movement. And many of these churches have realized that to deny this opportunity would be to lose worshipers, as it is possible to see in conversation with various gospel rappers who changed churches precisely because they could not be hop hopers or maintain the practices of the hip hop movement.

There were frequent reports of satisfaction from rappers when they said they could be in a church and make rap, as Culto Racional told us:

After I saw, I came to reconcile the two things. Because this way, when we came to church, I was speaking of the church, and not of Jesus, of the church, the two idioms are completely different. We come to a vision that you have to 
be a believer right off, you have to change everything without question. And I had this vision. Except that I always liked rap [...]. And from there I opened my mind, that I could be different. [...] Tell them to make music.”

It was with this possibility that Culto Racional was formed. The $5 \mathrm{mem}$ bers attend the Igreja Quadrangular and they have permission to perform at various church events. We were able to accompany one of the group's performances at an event held by the Igreja Quadrangular do Bairro Procasa (São José). The event was set for 7 PM and when it was nearly 8 the action began on stage. They could not be late because the show would end at 10 PM. The entrance of the two rap groups; Rapóstolos and Culto Racional, was received with great enthusiasm. In addition to the music there were constant words of praise such as Glória Deus. Everyone accompanied the show with great euphoria and recognized in it references to the proximity to God and a distance from the world of drugs, violence and greed.

Within the gospel style, the initial RAP came to mean Resgate de Almas Perdidas (Rescue of Lost Souls). Rap served as a way to Evangelize and was defended by many, but it was also the opportunity that many had to remain in church and continue to do rap, as Culto Racional told us: "We met some resistance, the churches where we went to play asked us to take off our caps, they did not want us to go on stage." To remove a cap upon entering any church is something seen as a sign of respect, but to sing rap without a cap, even if it is on the altar or stage of a church is something difficult for a rapper to accept, as is mentioned here, even by someone who goes to church regularly. He explained:

We want to present the idea that a cap and pants, our style of clothes, are not going to interfere with our life with God. And God also is not concerned with this. [...] It is a question of doctrine. And when we form a tradition, whether it is religious or cultural, as you can see, it is cultural for you not to enter with a cap in a closed place, it is cultural for you to not eat with your mouth open, it is cultural for you to use a fork in your hand, we say that everything is education, but in reality it is cultural [...]. The church emphasizes a doctrine and this was established in a way that created a large impediment for people, people thought that those who dress formally, in suits and ties, they are believers. But what we say a lot is to not look with your eyes but with the vision of the soul, because in reality what God wants is your heart. So that is the vision of the 
church. Just like there are churches that inhibit us a bit, we can mention a few that respect us, [...] and have this distinction, which is to have earned souls and moved the people to this."

As Culto Racional reminds us, it is culture that shapes our behavior, but he places God above the culture and constructs his justification for dressing and singing rap, proving that it is not this appearance, which is not always accepted that defines who is or who is not what they call a believer. For them it is the work that establishes the distinction and not the clothes that they wear, and this is what is earning souls and moving people to something, as he emphasized at the end of his statement.

In addition to a way of dressing, for them, religion itself, like the churches, is not what is most important, as a number of them made a point of emphasizing, but the Surrendering of life to Christ, regardless of the church. Perhaps this type of position allows greater liberty in the choice of a church at the time of professing one's faith. These youth appear to be causing these churches to rethink their conduct in the sense of allowing the manifestations of these musical practices.

At all the presentations it is common to find rappers who before or after singing offer testimony and talk about their experiences. This is a characteristic that stands out in gospel rap. In all these statements the emotions are experienced with great intensity. In these experiences presented in public, crying, followed by joy and thanks to God, can be freely expressed and with enthusiastic support from the audience.

But this experience is a component of a performance that constitutes this style of rap on stage and is also a characteristic that distinguishes them off stage. Discussion of this change is widely shared, and gives the impression that the repetition of these accounts serves to confirm the change in their lives and of rap itself. The desire to speak to someone was so great that it was the target of jokes. At one of these events, the DJ on stage, who had just given a presentation, was beginning a short prayer. But first he began to say, in a playful tone, the he would be brief, since it was the last day of the Brazil Cup, in which the local team Figueirense (SC) was playing against Fluminense (RJ) for the title and many people wanted to watch this important sporting event that was taking place in the city. When he mentioned the name of Figueirense, many people cheered. To emphasize that he would be brief he said: Before that guy offers another witness, which was met with smiles 
and support, including from that guy, who was still present.

In the stage presentations of gospel rap groups the prayers and preaching could be in the music itself, although this is not a rule, but those that include them cause great enthusiasm among the audience. This characteristic even appears to be associated to the names of the performers, like that of rapper Pregador [Preacher] Luo and the group Apocalipse 16. To be an outstanding preacher is the goal of a number of these rappers. To be a preacher and rapper is something that in this musical style in many moments is combined and becomes indistinguishable.

All of these references to a Christian belonging are reinforced in the performance. It is through this performance that they are able to bring different churches together in the same space and with the same objective, which is to make rap a great instrument of God that can bring people together in his name. But it is not enough to be in a church and to try to find everything one needs to change one's life, because, as they say, God is not a recovery clinic. Each person must do his or her part. This is an issue that a number of these rappers raise, given that even if they believe that the only form of salvation is through surrendering their life to Jesus, this surrender is defined by attitudes, and by changes in practices that are essential in their lives and in rap itself.

\section{Gospel rap bringing aesthetic-musical redefinitions}

To perceive the context in which this music is constructed is definitive of their sense of belonging to a common context. This characteristic is accentuated among those who make quebrada rap, reinforcing this belonging to a social, cultural and symbolic space, which emerges from their music and which in gospel rap is shifted to faith. But what music is this? Many rappers define their music with responses such as: A music that tells the truth, which does not exempt them from criticizing music of other groups in terms of how to create these truths. As Negrociação told us: Rap has this element of wanting to speak a true song and at times people wind up lying a bit, telling too much of the truth.

When I asked: what is truth? I often heard the emphatic response: It is what we sing, without a need for greater explanations. The direct responses they gave appear to say that rap is defined by singing the truth, for this reason what they sing is the truth. But what truth is this? This truth can be defined here as an interpretation, in the molds of Geertz (1989), of the 
experience of a social condition based on relations of inequality. The interpretation about these experiences is what generates the truth sung in the raps. As interpretations, this can only be one of many others that may exist. If on one hand this truth takes the form of a critical discourse, as is the case of quebrada rap, on the other, it is linked to issues of religious faith, as is the case of gospel rap.

More than music, rap is for many of these youths a form of expression that speaks about their experiences. They are parts of invisible cities, combative experiences, inequalities, emotional accounts that reveal factors that traditionally do not appear to fit in the poetry of a musical composition. It may appear illogical to sing of violence and drug dealing through poetry, even in gospel rap. At first glance it also does not appear to make sense to speak of a partnership between rap and religious faith. But it does, exactly because they are part of the common daily experience of these youth and if rap is associated to their experiences and subjectivities, to a truth, there is space in it for these debates and questions. In the case of gospel rap, the option for religious conversion can also mean a distancing from problems to which many are subject, such as violence. Both the rap, as well as the religious experience are presented as forms of rescue and for this reason become legitimate as aesthetic-musical manifestations that question the social conditions to which many of these youths are subject.

For these youth, rap becomes a way to be and coexist with what they question. Mainly because questions related to violence and other problems, directly or indirectly interfere with their lives. In this context it is possible to perceive an approximation with some ethnomusicological ethnographies. The first approximation refers to the perspective that expands the concept of music, emphasizing that it is not only made by professional musicians or specialists. Blacking (1973) tells us that for the Venda, musical practice is accessible to everyone, there are no musicians because music is in everyone. It is like this for the Suyá who inhabit the lands of Central Brazil, for whom there are no specialists in music, since everyone, especially the men, are involved in its practice. "Music is a specific form of communication. Its nonverbal characteristics make it a special vehicle for transmitting values and ethos that are more easily expressed "musically" and verbalized. These are communications made not only through sounds, but also through the movements of interpreters, time, location and the conditions in which they are 
executed." (SEEGER, 1980, p. 84). Rap has this character within the hip hop movement. Aspects such as violence, inequality and social and even individual problems related to them are "expressed musically."

Music is seen in the culture through medium that allow the rise of the musicality in question, the socio-cultural system defines this music and in the case of gospel rap, it also establishes musical redefinitions. Based on certain concepts of the world that allow the emergence of this urban musicality, rap is related to distinct cultural contexts, which are united in an appropriation of this music as a form of expressing a social experience, whether it is racial or gender discrimination, or inequalities generated by poverty, by the consequences of immigration, or by aesthetic-religious experiences. In this case, they are socio-cultural contexts that provide this musicality, which does not eliminate the possibility for this music to be appropriated in other contexts.

Far from a homogeneous idea about music, to think it, observe it, study it, presents us a complexity that is impossible to circumvent. There is a bibliography that offers us a vast discussion about music in a wide variety of contexts and this implies considering it in this way, in the cultural context in which it is produced. But it is insufficient to study, understand, and know music, it is necessary to feel it and perceive it through the interaction that it establishes. Music is a form of communication and mediation.

For the Guarini indigenous groups studied by Montardo (2009, p. 41), this importance of music goes along with the group's creation myth through which the Shaman has responsibility "to conduct the group, promoting the maintenance of the songs, of the dances and of the sound of the musical instruments, without which the Land would be destroyed." Shamanism is of central importance in Guarani culture and music is determinant not only for the existence of the group, but for humanity. There is here a self-responsibility that goes beyond their culture and the music allows its compliance in a complex process of musical composition.

In an interaction with the environment, Guarani culture allows, through this music, exercising this responsibility given that "there is no possibility of life on Earth if the Guarani are not singing and dancing," as a number of them state in various subgroups, as reported by Montardo (2009, p. 13). "The Sun, or the owner of the Sun, the creator-hero, is responsible for maintaining the sound of the world during the day. At night, this responsibility is that of men," she added. This is a concept of music that implies an agency of the 
Guarani in relation to the responsibilities that they have to contribute to the order that guides them.

To speak of music is also to speak of its diversity. What each person or group, based on the culture(s) in which they are found defines as being music is only one of the countless ways to conceive it. What is music for some is not for others, and the opposite is also true. In the hip hop movement, music circulates through cultures and is remade in each cultural context. It is a music that is characterized in the movement and is permeated by many cultures. This music implies "responsibilities," which can be expressed from a commitment that they attribute to themselves to provide an account of a reality that contains a truth whether it is of the streets, of history, of the Bible, or however they define it.

\section{References}

ATTALI, Jacques. 1992. Noise: the Political Economy of Musica. Minneapolis: University of Minnesota Press.

BAKHTIN, Mikhail. 2003.“Os gêneros do discurso”. In: Estética da criação verbal. São Paulo: Martins Fontes. pp. 261-306.

BASTOS, Rafael José M. 2007. “A origem do samba como invenção do Brasil: sobre 'Feitio de oração' de Vadico e Noel Rosa (porque as canções têm música)”. Florianópolis: UFSC - PPGAS. Coleção: Antropologia em Primeira Mão.

BASTOS, Rafael José M. 2007. 1995. “Esboço de uma antropologia da música: para além de uma antropologia sem música e de uma musicologia sem homem”, Anuário Antropológico, 93:9-73.

BAUMAN, Richard. 1977. "Verbal art art as performance". In: Verbal art as performance. Massachusetts: Newbury House Publishes. pp. 3-51.

BLACKING, John. 1973. How music is man? Seattle: University of Washington Press.

BOURDiEU, Pierre. 1994. “Gostos de classe e estilos de vida”. In: R. Ortiz(org.), Pierre Bourdieu. 2a.ed. São Paulo: Atica. pp. 82-121. CIDRA, Rui. 2002. "Ser real: o RAP na construção de identidades da área metropolitana de Lisboa”. Etnologia, 14(12): 189-222. CONTADOR, Antônio. C.; FERREIRA, E. L. 1997. Ritmo \& poesia: os caminhos do RAP. Lisboa: Assírrio \& Alvim. 
DAYRELL, Juarez. 2005. A música entra em cena: o RAP e o funk na socialização da juventude. Belo Horizonte: Ed. UFMG.

ELIAS, Norbert. 1995. Mozart: sociologia de um gênio. Rio de Janeiro: Jorge Zahar.

FELD, Steven. 1982. Sound and sentiment: birds, weeping, poetics and song in Kaluli expression. 2. ed. Philadelphia: University of Pennsylvania Press.

FRADIQUE, Teresa. 2003. Fixar o movimento: Representações da música RAP em Portugal. Lisboa: Dom Quixote.

FRITH, Simon. 1988. Music for pleasure: essays in the sociology of pop. New York: Routledge.

FERRY, Luc. 1994. Homo aestheticus. São Paulo: Ensaio.

GEERTZ, Clifford. 1989. A interpretação das culturas. Rio de Janeiro: Guanabara Koogan.

HERSCHMANN, Micael. 2005. O funk e o Hip Hop invadem a cena. 2a. ed. Rio de Janeiro: Ed. UFRJ.

HERSCHMANN, Micael. (org.) 1997. Abalando os anos 9o, funk e Hip Hop: globalização, violência e estilo cultural. Rio de Janeiro: Rocco.

MAFFESOLI, Michel. 1987. Dinâmica da violência. São Paulo: Editora Revista dos Tribunais; Edições Vértice.

MONTARDO, Deise Lucy Oliveira. 2009. Através do MBARAKA: música, dança e xamanismo guarani. São Paulo: Edusp.

NOVAES, Regina. 1999. “Ouvir para crer: Os Racionais e a fé na palavra”. Religião \& Sociedade, 2o(1): p.65-92.

RIAL, Carmen. Rodar. 2008. "A circulação dos jogadores de futebol brasileiros no exterior". Horizontes Antropológicos, 30: 21-65.

ROSE, Tricia. 1994. Black noise: rap music and black culture in contemporany America. Hanover and London: University Press of New England.

ROSEMAN, Marina. 1993. "Remembering to forget: the aesthetics of longing". In: Healing sounds from the malaysian Rainforest: Temiar music medicine. Los Angeles/Londres: University of California Press. pp. 186-201.

SEEGER, Anthony. 1980. Os índios e nós: estudos sobre sociedades tribais brasileiras. Rio de Janeiro: Campus.

SEITEL, Peter. 1999. “Introduction”. In: The powers of genre: interpretig Haya oral literature. New York: Oxford University Press. pp. 03-32.

SOUZA, Angela Maria de. 1998. O movimento do RAP em Florianópolis: "a ilha da magia é só da ponte pra lá!”. Dissertação de Mestrado, PPGAS-UFSC, 
Florianópolis.

SOUZA, Angela Maria de. 2009. "A caminhada é longa e .... o chão tá liso": O movimento hip hop em Florianópolis e Lisboa. Tese de Doutorado, PPGASUFSC, Florianópolis.

TAGG, Philip. 2004. "Para que serve um musema? Antidepressivo e a gestão musical da angústia”. V Congresso da IASPM - LA, junho de 2004.

VELHO, Gilberto. 1999. Individualismo e cultura: notas para uma antropologia da sociedade contemporânea. Rio de Janeiro: Zahar.

VELHO, Gilberto. (org.) 1999. Antropologia urbana: cultura e sociedade no Brasile em Portugal. Rio de Janeiro:Zahar.

VELHO, Gilberto. 2003. Projeto e metamorfose - antropologia das sociedades complexas. 3a. ed. Rio de Janeiro: Zahar.

VIANNA, Hermano. 2003. Galeras cariocas: territórios de conflitos e encontros culturais. 2a. ed. Rio de Janeiro: Ed. UFRJ.

VIANNA, Hermano. 1998. O mundo funk carioca. Rio de Janeiro: Zahar. WIEVIORKA, Michel. (org.) 1997. Um nouveau paradigme de la violence? Paris/ Montreal: L'Harmattan.

\section{Audio references:}

ARMA-ZEN. 2006. A caminhada élonga... e o chão tá liso. Florianópolis: Selo Cano Serrado.

CHULLAGE. 2004. Rapensar: passado, presente, futuro. Lisboa: Lisafonia. REALIDADE SBA. 2001. Lutando para vencer. Florianópolis: CD Independente. REVERSO. 2007. A humildade precede a honra. Florianópolis: CD Independente. VÁRIOS. 2005. Rap Floripa - volume 1. Florianópolis: CD Independente.

\section{Angela Maria de Souza}

Professor at the Universidade Federal da Integração Latino-Americana UNILA.

Post-doctoral studies at the Inter-disciplinary Graduate Program in Human Sciences UFSC.

Researcher at NAVI - Center for Audiovisual Anthropology and Studies of the Image, and at GAUM - the Urban and Maritime Anthropology Group. | Doctor in Social Anthropology from the Graduate Program in Social 
Anthropology - UFSC - Thesis: A caminhada é longa... e o chão tá liso: o

Movimento hip hop em Florianópolis e Lisboa (2009).

Recent Publications:

SOUZA, Angela Maria de. Deslocamentos na cidade: o Movimento hip hop nos bairros de Florianópolis. Revista de Ciências Humanas.

Florianópolis, UFSC, out. 2009. Vol. 43, n. 2. p. 549 - 562.

SOUZA, Angela Maria de. Dialogues between suburbs: the globalization of the hip hop movement. Set.2010. Disponível em: http://blogs.nyu.edu/ projects/materialworld/2010/og. SOUZA, Angela Maria de. A aventura do rap em Florianópolis: musicalidades urbanas no Movimento hip hop. Prêmio Silvio Coelho dos Santos. Fundação Cultural Franklin Cascaes. (no prelo a ser publicado em marços 2011).

Address:

Servidão Bambuzal, 170 - Rua Pau de Canela. Bairro Campeche. Florianópolis. 88063-505.

Telephones: $48-33383132$ and $45-91456984$

E-mail: angela.souza@unila.edu.br

\section{Deise Lucy Oliveira Montardo}

Professor in the Anthropology Department and the Graduate Social Anthropology Program (PPGAS) at UFAM. Coordinator of the research group in Art, Culture and Society and member of the Center for Amazon Indigenous Studies (NEAI), both at UFAM. Participant in the research center "Art, culture and society in South America and the Caribbean" (MUSA) at UFSC. Doctor in Social Anthropology from USP. Author of the book Através do MBARAKA: Música, dança e xamanismo guarani. São Paulo: Edusp, among other publications.

Address: CP 3684, Rua do Comércio, Parque Dez. Manaus / AM 69055971.

Telephone : 92 - 91331111

E-mail: deise.lucy@pq.cnpq.bre deiselucy@gmail.com

Received 30 September, 2010, approved 17 January, 2011 